\title{
Development of a simulation model of process control systems as a tool in modern training technology
}

\author{
Nikolaienko A., Yakushevich I.* \\ Engineering Institute of Zaporizhzhya National University, Zaporozhye, Ukraine
}

Received: $05.12 .2019 \quad$ Accepted: 25.12 .2019

\begin{abstract}
The article substantiates the need to develop practical recommendations in the form of a process control system simulation model for employees of enterprises who master the production of aluminum wire rod on a casting and rolling unit without sufficient technological support and equipment with automation systems. Mathematical dependences, automation systems and control algorithms are proposed, with the help of which it is possible to implement automatic process control modeling, understand the features of the technological process, adjust it to a given operating mode, study the influence of input parameters on the quality of regulation and gain some experience in setting up and maintaining an automatic process control system. The simulation model of the automated control system was created on the basis of a single computer using the Unity Pro programming packages produced by Schneider Electric and TIA Portal of Siemens company. Unity Pro was used to develop simulation and process control programs and TIA Portal ", which has ample opportunities for creating a humanmachine interface, was used to develop an automated workstation for an operator-technologist. The connection between these packages is implemented using the appropriate settings in each of them. The operator's workstation contains three basic windows for visualizing various sections of the technological line with the display and animation of mechanisms, control panels for their work and means of monitoring technological parameters. To configure the process control system, set up the production line and conduct research in each window, you can call up a panel with tuning parameters, activation of disturbing influences and graphs of changes in controlled quantities. The control system simulator software allows you to implement two manual control modes for the casting and rolling unit - free and interlocked, as well as automatic. All this creates opportunities to simulate various situations in the operation of the furnace department and the casting and rolling unit, as well as gain some experience as an operator of automated workplaces and as a setup manager for aluminum process control systems.
\end{abstract}

Key words: simulation model, casting and rolling unit, algorithm, programming, automation system.

\section{Розробка імітаційної моделі АСУТП, як засобу в сучасній технології навчання}

\author{
Ніколаєнко А. М., Якушевич І. В. \\ Інженерний інститут Запорізького національного університету, Запоріжжя, Україна
}

\begin{abstract}
Анотація. Стаття присвячена створенню імітаційної моделі АСУТП для викладачів, які навчають студентів за спеціальністю автоматизація та працівників підприємств, які освоюють виробництво алюмінієвої катанки без достатнього технологічного супроводу. Запропоновано математичні залежності, системи автоматизації та алгоритми управління, за допомогою яких можна реалізувати моделювання АСУТП, зрозуміти особливості технологічного процесу, налаштувати його на заданий режим роботи, дослідити вплив вхідних параметрів на якість регулювання і отримати певний досвід роботи з налагодження та обслуговування АСУТП. Імітаційна модель автоматизованої системи управління створена на базі однієї ЕОМ за допомогою пакетів програмування Unity Pro виробництва Schneider Electric і TIA Portal компании Siemens. Unity Pro використовувався для розробки програм моделювання та управління технологічними процесами, а TIA Portal, у якого $€$ широкі можливості для створення людино-машинного інтерфрейсу, застосовувався для розробки автоматизованого робочого місця оператора-технолога. Зв'язок між цими пакетами реалізовано за допомогою відповідних налаштувань в кожному з них. АРМ оператора містить три базових вікна візуалізації різних ділянок технологічної лінії з відображенням і анімацією механізмів, пультів управління їх роботою і
\end{abstract}

Corresponding Author: Nikolaienko Anatoliy Mykolayovych. Phone. +38(097)926-08-02 . E-mail: tetra@ukr.net Engineering Institute of Zaporizhzhya National University, 12 Jubilee Ave.41, Zaporizhzhya, Ukraine, 69006.

Відповідальний автор: Ніколаєнко Анатолій Миколайович. Тел. +38(097)926-08-02 . E-mail: tetra@ukr.net. Інженерний інститут Запорізького національного університету, пр. Ювілейний, 12, кв. 41, Запоріжжя, Україна, 69114. 
засобами контролю за технологічними параметрами. Для настройки АСУТП, налагодження технологічної лінії і проведення досліджень в кожному вікні можна викликати панель з настроювальними параметрами, активізацією збурень і графіками зміни регульованих величин. Програмне забезпечення імітатора АСУТП дозволяє реалізувати два ручних режиму управління ливарно-прокатним агрегатом - вільний і зблокований, а також автоматичний. Все це створює можливості для імітації різних ситуацій в роботі пічного відділення і ливарно-прокатного агрегату, а також придбання певного досвіду роботи в якості оператора APM i наладника АСУТП з виробництва алюмінієвої катанки.

Ключові слова: імітаційна модель, ливарно - прокатний агрегат, алгоритм, програмування, система автоматизації.

\title{
Разработка имитационной модели АСУТП, как средства в современной технологии обучения
}

\author{
Николаенко А. М., Якушевич И. В. \\ Инженерный институт Запорожского национального университета, Запорожье, Украина
}

\begin{abstract}
Аннотация. Статья посвящена разработке имитационной модели АСУТП для преподавателей, которые обучают студентов по специальности автоматизация и работников предприятий, которые осваивают производство алюминиевой катанки без достаточного технологического сопровождения. Предложены математические зависимости, системы автоматизации и алгоритмы управления, с помощью которых можно реализовать моделирование АСУТП, понять особенности технологического процесса, настроить его на заданный режим работы, исследовать влияние входных параметров на качество регулирования и получить определённый опыт работы по наладке и обслуживанию АСУТП. Имитационная модель автоматизированной системы управления создана на базе одной ЭВМ с помощью пакетов программирования Unity Pro производства Schneider Electric и TIA Portal компанії Siemens. Unity Pro использовался для разработки программ моделирования и управления технологическими процессами, а TIA Portal, у которого есть широкие возможности для создания человеко-машинного интерфейса, применялся для разработки автоматизированного рабочего места оператора-технолога. Связь между этими пакетами реализована с помощью соответствующих настроек в каждом из них. АРМ оператора содержит три базовых окна визуализации различных участков технологической линии с отображением и анимацией механизмов, пультов управления их работой и средствами контроля за технологическими параметрами. Для настройки АСУТП, наладки технологической линии и проведения исследований в каждом окне можно вызвать панель с настроечными параметрами, активизацией возмущающих воздействий и графиками изменения регулируемых величин. Программное обеспечение имитатора АСУТП позволяет реализовать два ручных режима управления литейно-прокатным ангрегатом - свободный и сблокированный, а также автоматический. Всё это создаёт возможности для имитации различных ситуаций в работе печного отделения и литейно-прокатного агрегата, а также приобретения определённого опыта работы в качестве оператора АРМ и наладчика АСУТП по производству алюминиевой катанки.
\end{abstract}

Ключеые слова: имитационная модель, литейно--прокатный агрегат, алгоритм, программирование, система автоматизации.

\section{Bcmyn}

Підвищення якості освіти неможливо без впровадження в навчальний процес передових технологій, серед яких особливе місце займає технологія імітаційного моделювання. При використанні цього методу створюються умови, при яких у студентів з'являється можливість придбання певних професійних якостей не на виробництві, а в навчальних аудиторіях на імітаційних стендах, що моделюють реальні виробничі процеси [1-3]. Дана технологія навчання також використовується на виробництві. За допомогою імітаторів-тренажерів оперативний і технологічний персонал відпрацьовує базові навички роботи з системами управління та дії в аварійних ситуаціях без ризику вплинути на хід реального технологічного процесу [4-6]. Одночасно з підготовкою кадрів імітаційні моделі дозволяють вирішувати широке коло завдань, що виникають при проектуванні АСУТП, дають можливість одночасного розгляду і оцінки декількох альтернативних варіантів проектних рішень, сприяють швидкому налагодженню програмного забезпечення мікропроцесорних контролерів і людиномашинного інтерфейсу в автоматизованих системах управління [7].

Основними складовими таких імітаційних моделей $€$ математичне описання технологічного процесу, за допомогою якого можна провести необхідні дослідження і встановити ступінь впливу того чи іншого вхідного параметра на стан моделі, та комп`ютер з відповідним програмним забезпеченням і 
зручним людино-машинним інтерфейсом, який допоможе зрозуміти особливості технологічного процесу, визначитися з оптимальними параметрами та настройками і відпрацювати необхідні дії з боку людини. Усе це є важливим і для студента, який освоює спеціальність, і для виробничника, що підвищує свою кваліфікацію, і для проектувальника АСУТП. Тому при створенні імітаційної моделі необхідно тільки дотримуватися вимогам, які пред'являються до неї, а для кого вона призначена і як з нею працювати має визначати подальша методична розробка.

Причиною створення імітаційної моделі АСУТП з виробництва алюмінієвої катанки на ливарнопрокатному агрегаті стали обставини, що виникли в Україні після закриття в 2011p. Запорізького алюмінієвого комбінату. Аби задовольнити потреби на його продукцію окремі малі підприємства стали самостійно налагоджувати виробництво алюмінієвої катанки, закуповуючи в Китаї ливарно-прокатні агрегати за вигідною ціною без достатнього технологічного супроводу і оснащення системами автоматизації. Проте відсутність чітких інструкцій, систем автоматичного регулювання, кадрів, здатних обслуговувати нове обладнання, істотно ускладнили пусконалагоджувальні роботи і в цілому експлуатацію технологічної лінії безперервного лиття та прокатки. У зв'язку з цим виникла необхідність у розробленні практичних рекомендацій, які допомогли б на подібних підприємствах самостійно освоїти виробництво алюмінієвої катанки, зрозуміти алгоритми регулювання основних технологічних параметрів, роботу систем автоматизації і отримати певний досвід в управлінні та обслуговуванні. Щонайкраще виконання поставленого завдання можна реалізувати на базі імітатора, який моделює технологічний процес і надає інформацію про його стан через інтерфейс автоматизованої системи управління технологічними процесами. Така розробка також $є$ корисною і для вищих навчальних закладах де використання імітаційних моделей в навчальному процесі суттєво покращує спеціальну підготовку студентів.

Мета роботи: розробити імітатор АСУТП з виробництва алюмінієвої катанки, як наочний порадник для виробничників, що самостійно опановують технологію неперервного лиття та прокатки і, як засіб навчання для викладачів вишів, що працюють зі студентами відповідних спеціальностей.

\section{II Матеріал і методи дослідження}

Технологічна лінія з виробництва алюмінієвої катанки зазвичай складається з пічної дільниці, ливарної машини, лінії транспортування литої заготовки до прокатного стану, прокатного стану і моталок (рис.1) [8]. За допомогою скіпа завантажувальної машини 1 алюмінієві брикети подаються у газову плавильну піч шахтного типу 2. Після розплавлення метал прямує в одну з двох роздавальних печей 3, де він очищується від шлаку, піддається дегазації 4 та направляється у жолоб ливарного колеса 5, охопленого сталевою стрічкою. Під впливом охолодної води розплавлений алюміній кристалізується у виливниці колеса, що обертається, та у вигляді безперервного зливка подається у прокатний стан за допомогою правильного 6 і переднього тягового 7 пристроїв. У разі незадовільної якості лиття заготовку розрізають гідравлічними ножицями 8 на дрібні мірні шматки до тих пір, поки вона не відповідатиме встановленим вимогам.

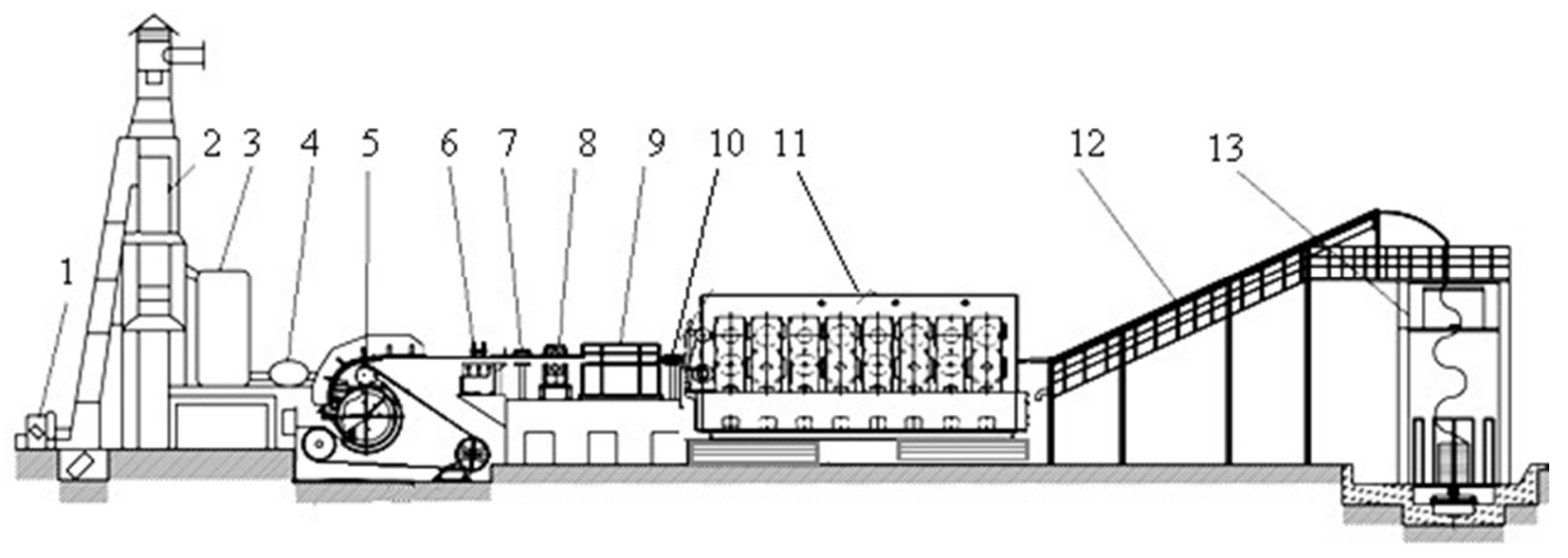

Рис. 1. Технологічна лінія неперервного лиття та прокатки 
Під час виробництва дроту з алюмінієвих сплавів заготовку перед прокаткою додатково нагрівають індукційним нагрівачем 9 і за допомогою пристрою 10 подають у прокатний стан 11. Після прокатки катанка піддається процесам гартування, охолодження та сушіння 12 і подається на здвоєну моталку кошикового типу 13. Затискний тяговий пристрій разом з пристроєм утворення кілець укладає катанку в приймальний кошик, після наповнення якого відбувається заміна його на новий.

Відповідно до технології, для одержання високоякісної катанки необхідно підтримувати задану температуру розплаву у шахтній та роздавальних печах, забезпечити стабільні умови кристалізації рідкого металу у ливарному колесі,регулювати довжину алюмінієвої заготовки перед прокаткою, керувати охолодженням катанки під час прокатування у стані та процесом формування бунта у моталці. Оскільки властивості алюмінієвої катанки формуються протягом всього технологічного циклу, від плавильної печі до моталки [9], виконання усіх перелічених умов має відбуватися якісно. Тому до того, як розпочинати імітаційне моделювання АСУТП з виробництва алюмінієвої катанки, необхідно визначитися 3 математичними моделями об'єктів автоматизації, формулами та рівняннями, що описують зв'язок між окремими параметрами, а також алгоритмами керування технологічним процесом, за допомогою яких можна зрозуміти особливості виробництва катанки, створити системи автоматизації, дослідити вплив тих чи інших параметрів на якість регулювання і налагодити роботу ливарнопрокатного агрегату на бажаний кінцевий результат.

Виробництво катанки розпочинається з підготовки розплаву до лиття у шахтній та роздавальних печах. Важливою характеристикою рідкого алюмінію на цьому етапі $є$ його температура, яка має підтримуватися на заданому значені. Зазвичай на подібних об'єктах це відбувається з достатньою якістю за рахунок коригування витрати спалюваного газу [10], тому і при імітаційному моделюванні АСУТП використовувався саме цей спосіб.

Аби забезпечити стабільні умови кристалізації металу необхідно спочатку визначити загальну витрату охолодної води при заданих температурі заготовки на виході з кристалізатора та швидкості ливарного колеса [11]:

$$
G_{\kappa p}=\frac{Q_{\text {вod }}}{c_{6} \cdot \Delta T_{6}},
$$

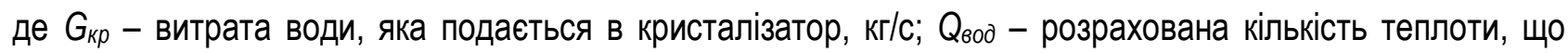
втрачається 3 охолодною водою при заданих температурі заготовки на виході з кристалізатора та швидкості ливарного колеса [12], Вт; $C_{8}$ - теплоємність води, Дж/(кг 'К); $\Delta T_{8}$ - різниця між температурою

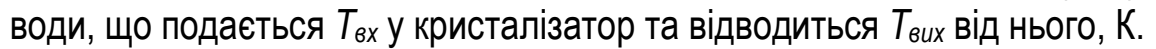

Потім розподілити її між окремими зонами кристалізатора [13]:

$$
G_{i}=\left(1+\frac{1}{z}-\frac{K_{i}}{K_{c p}}\right) \cdot 100 \%,
$$

де $G_{i}$ - витрата води на охолодження в $i$-ту зону кристалізатора, кг/с; $z$ - кількість зон охолодження; $K_{i}$ - коефіцієнт теплопередачі багатошарової стінки кристалізатора за напрямом охолодження в $i$-тій

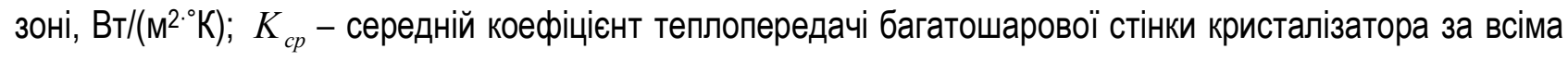

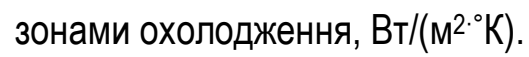

А після цього реалізувати комбіновану систему автоматичного регулювання теплового режиму [14], яка здійснює коригування загальної витрати води за розрахованою поточною величиною теплоти, що виноситься із заготовкою з кристалізатора $Q_{\text {заг }}[15]$ :

$$
Q_{\text {заг }}=\rho \frac{V}{60} \cdot F \cdot h_{n}-G_{\text {роз }} \cdot\left(h_{n}-h_{\kappa}\right),
$$

де $G_{\text {роз }} \cdot\left(h_{n}-h_{\kappa}\right)$ - теплота, що віддається гарячим теплоносієм, Вт; $G_{p о з}$ - витрата розплаву, що визначається продуктивністю агрегату та швидкістю лиття, кг/с; $h_{n}=L+c_{n} \cdot T_{n}$ - ентальпія сплаву на початку виливниці, Дж/кг; $h_{\kappa}=L+c_{\kappa} \cdot T_{\kappa}$ - ентальпія сплаву у кінці виливниці, Дж/кг; $T_{n}$ - початкова та 
$T_{\kappa}$ - кінцева температура алюмінієвого сплаву у виливниці, ${ }^{\circ} \mathrm{C} ; c_{n}, c_{\kappa}$ - теплоємність алюмінієвого сплаву, відповідно, для початкової та кінцевої температур, Дж/(кг $\left.{ }^{\circ} \mathrm{C}\right)$;

та розрахованою поточною величиною теплоти, що втрачається з охолодною водою $Q_{\text {вод }}$ :

$$
Q_{\text {вод }}=c_{в} \cdot G_{\text {в }} \cdot \Delta T_{\text {в }} \text {. }
$$

Стабілізація довжини алюмінієвої заготовки здійснюється за допомогою системи автоматичного регулювання, яка на підставі математичної моделі:

$$
L=L_{\text {заг. }}+\left(V_{\pi} \cdot c_{1}\left(T_{C}-T_{A}\right)+V_{J}-\frac{c_{2} n}{\lambda}\right) \cdot k \Delta t,
$$

де $L$ - загальна довжина алюмінієвої заготовки, м; $L_{\text {заг }}=V_{\pi} \cdot \Delta t$ - базова довжина отримуваного зливка за цикл лиття, м; $V_{\text {Л }}$ - лінійна швидкість заготовки на виході з ливарного колеса, м/c; $c_{1}-$ коефріцієнт температурного подовження алюмінію; $T_{C}$ - температура зливка на виході з ливарного колеса, К; $T_{A}$ - температура металу на вході в ливарне колесо, К; $k$ - кількість циклів лиття; $c_{2}-$ коефріцієнт передачі швидкості прокатного стана; $n$ - швидкість обертання електропривода; $\lambda$ коефіцієнт витяжки прокатного стана; $\Delta t$ - цикл лиття, с;

працює не тільки за довжиною заготовки, а і за збуреннями, що надходять з боку ливарного колеса і прокатного стану [16].

Охолодження катанки під час прокатування її у стані здійснюється шляхом керування витратою охолодної емульсії за температурою катанки на виході зі стану.

Формування бунта готової катанки 3 властивостями, що забезпечують бажаний режим охолодження, реалізується шляхом керування кутової швидкості обертання проводки виткоутворювача моталки [17]. При цьому швидкість для і-того витка змінюється ступінчасто, відповідно до виразу:

$$
\varpi_{i}=\frac{V}{R_{\max (\min )} \mp(i-1) d \cdot \alpha},
$$

а тривалість керування, яка дорівнює часу фрормування $i$-того витка, визначається із співвідношення:

$$
T_{i}=\frac{2 \pi}{\varpi_{i}} .
$$

Тут $\varpi_{i}$ - кутова швидкість обертання проводки, рад/с; $V$ - швидкість подачі катанки, м/c; $R_{\max }-$ радіус максимального витка, м; $R_{\min }$ - радіус мінімального витка, м; $d$ - діаметр катанки, м; $1 \leq i \leq m$, $m=\frac{R_{\max }-R_{\min }}{d \cdot \alpha}-$ кількість витків у шарі, $\alpha-$ крок укладання витків, $1 \leq \alpha \leq \frac{R_{\max }-R_{\min }}{2 d}$, « $R_{\max }$-» при укладанні шару від перифрерії до центру, « $R_{\min }+»-$ при укладанні шару від центру до периферії.

Як видно з наведених формул та алгоритмів керування вони відображають зв'язки між окремими технологічними параметрами на кожній дільниці технологічної лінії і відповідають вимогам, висунутим до математичного забезпечення створюваної імітаційної моделі АСУТП.

\section{III Результати}

Імітаційна модель (імітатор) технологічної лінії неперервного лиття і прокатки алюмінієвої катанки розроблена на одній обчислювальній машині з використанням пакетів програмування UnityPro виробництва Schneider Electric [18] і TIA Portal компанії Siemens [19]. За допомогою UnityPro створені програми моделювання та керування технологічними процесами і агрегатами, а TIA Portal, який має широкі можливості у створенні людино-машинного інтерфейсу, використовувався для розробки автоматизованого робочого місця (APM) оператора-технолога. Зв'язок між цими пакетами було створено за допомогою відповідних настройок у кожному з них. У програмі Unity Pro здійснили підключення до мережі Ethernet. Вказали тип модуля контролера Modicon, що підтримує цю мережу та його IP-адресу. В програмі TIA Portalстворили та настроїли Ethernet-мережу і вказали драйвер з'єднання з контролерами серії Modicon, IP-адресу Ethernet-модуля та маску підмережі. При створенні проекту усі 
об'єкти автоматизації апроксимовані інерційними ланками із запізнюванням, а код програми, що моделює роботу агрегатів та систем автоматизації з відповідною анімацією на екрані імітатора, створено FBD - i ST- мовами. Архітектура розробленого проекту приведена на рисунку 2.

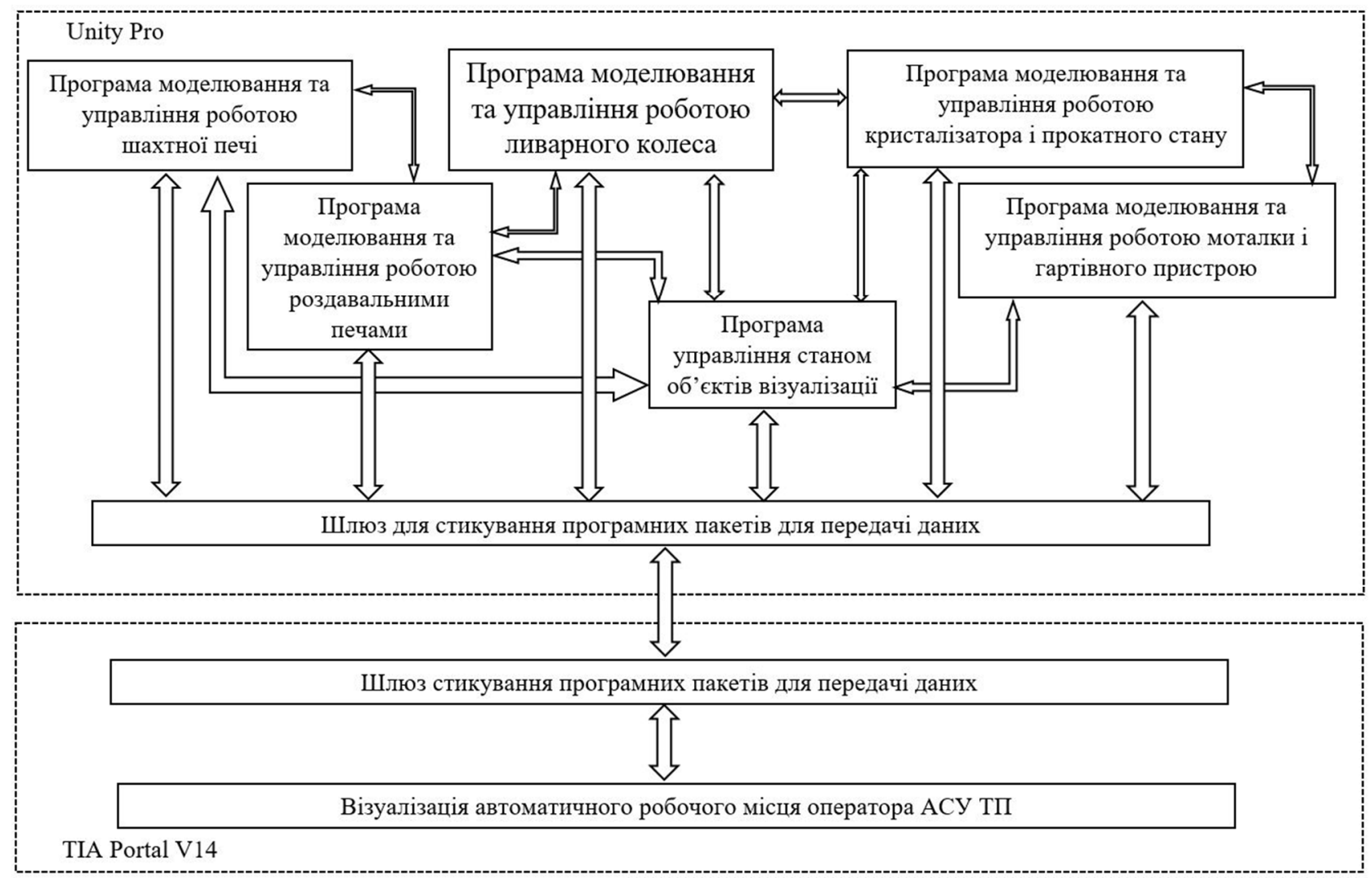

Рис. 2. Архітектура імітаційної моделі АСУТП з виробництва алюмінієвої катанки на ливарно-прокатному агрегаті

Основою для спілкування людини з імітатором є екран ЕОМ, в якому за допомогою миші та меню можна вибрати три базових вікна візуалізації окремих дільниць технологічної лінії. В кожному з цих вікон зображені відповідні агрегати та механізми з технологічними лініями зв'язку, а також пульти керування 3 кнопками вибору режимів роботи, ручного або автоматичного, та засобами контролю за технологічними параметрами. Для налагодження та дослідження роботи технологічної лінії в кожному 3 вікон можна викликати панель коригування коефріцієнтів моделей окремих об'єктів автоматизації, настроювання параметрів регулятора та активізації збурень, що впливають на хід технологічного процесу. Результат досліджень представляється у вигляді графіка зміни контрольованої величини.

У першому вікні імітатора зображені шахтна та дві роздавальні печі 3 відповідними технологічними лініями зв'язку, а також пульти керування з кнопками вибору режимів роботи, ручного керування та засобами контролю за рівнем і температурою металу в печах (рис. 3).

Програмою передбачено завантаження шахтної печі алюмінієвим ломом, увімкнення її в роботу, ручне і автоматичне регулювання температури розплаву на рівні $750{ }^{\circ} \mathrm{C}$, зливання його в одну 3 роздавальних печей з автоматичною стабілізацією температури $\left(700^{\circ} \mathrm{C}\right)$. Після злиття розплаву простір печей можна провітрити вентиляторами.

Програма моделювання роботи шахтної печі приведена на рисунку 4. Функціональний блок1 реалізує пуск програми в роботу, блоками 2 і 3 запрограмовані ПІ регулятор і алгоритм керування його настройками. Інерційною ланкою 4 і транспортним запізнюванням 7 представлена шахтна піч. Формування збурень реалізовано у блоці 6 , а у фрагменті 8 вихідні сигнали регуляторів перетворюється у реальну витрату газу та повітря, що надходять до пальників. Дозвіл на злив розплаву з шахтної печі реалізовано у блоці 9 . 


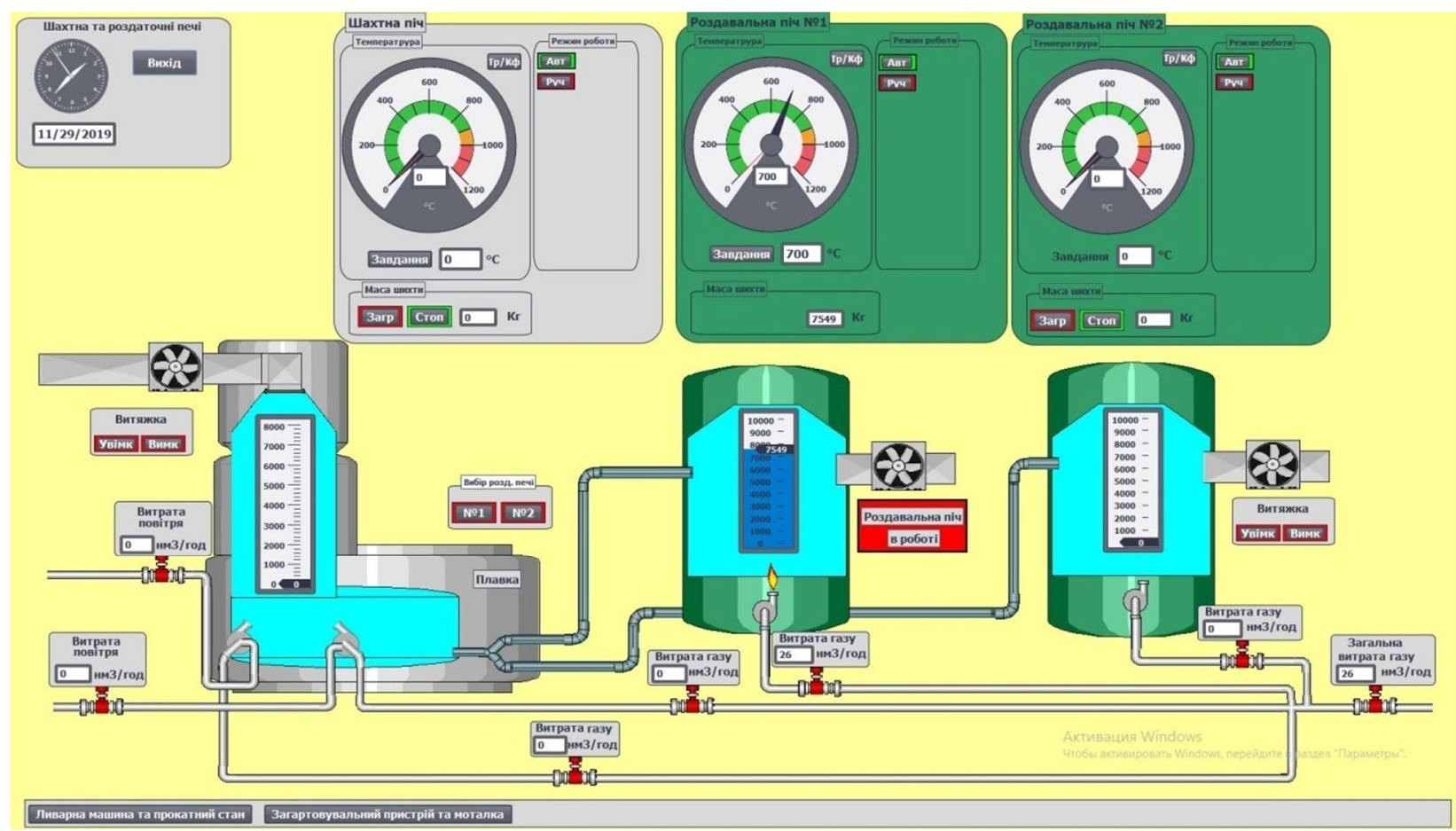

Рис. 3. Вікно візуалізації пічної дільниці

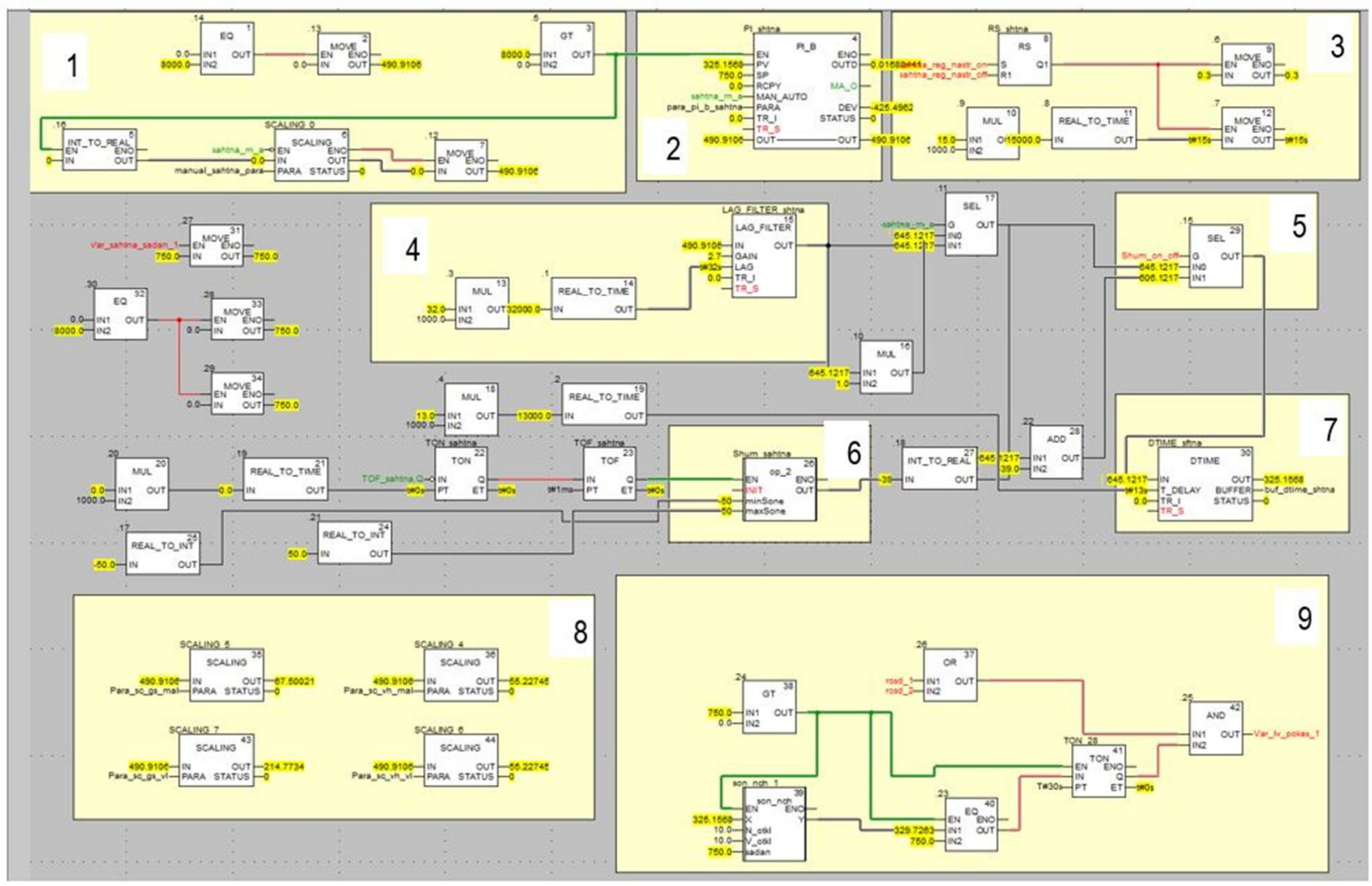

Рис. 4. Програма моделювання роботи та анімації шахтної печі

Панель установлення параметрів об'єкта, настройок регулятора та активізації збурень, що випадково з'являються у системах автоматизації, показана на рисунку 5. 


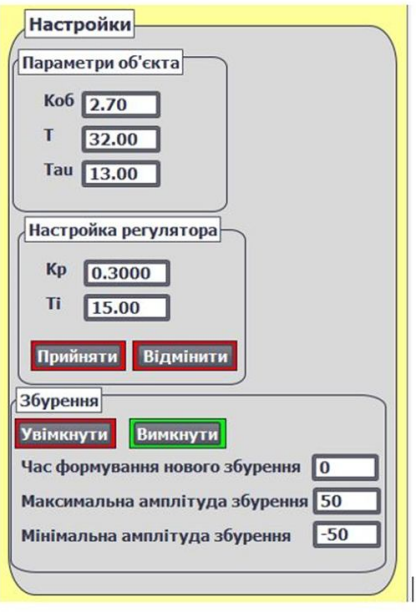

a)
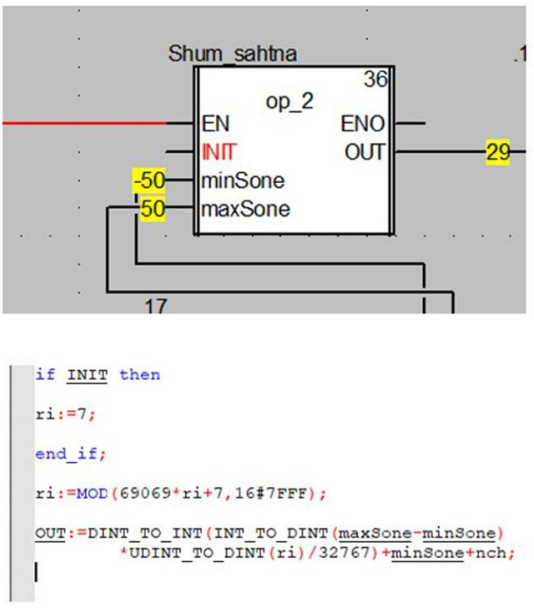

б)

Рис. 5. Панель настроювання системи автоматичного регулювання (а) та програмний блок формування випадкових збурень (б)

У другому вікні показані ливарна машина із заготовкою та прокатний стан з пультами керування роботою агрегатів і приладами, що показують значення регульованих параметрів (рис.6).

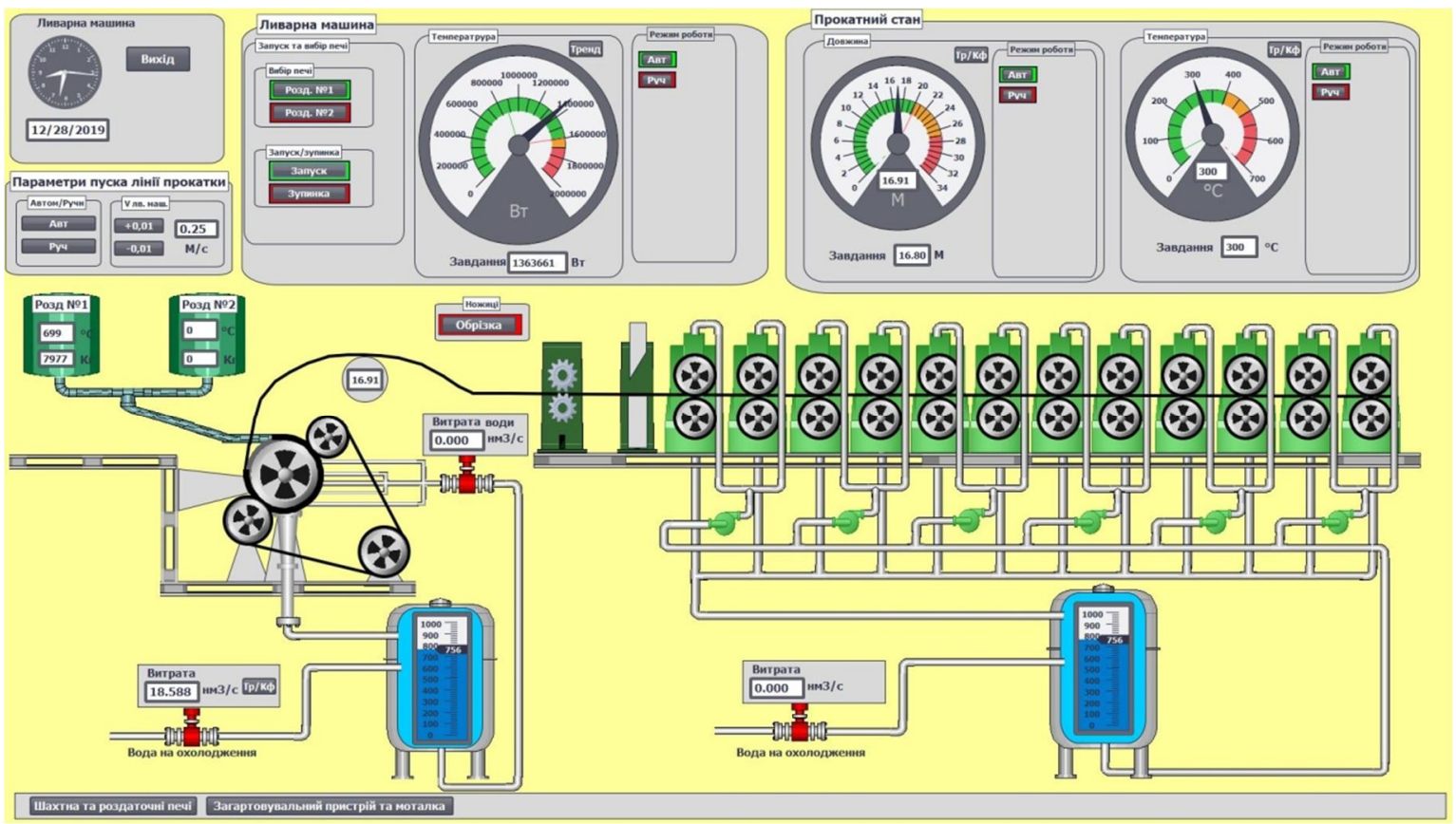

Рис. 6. Вікно візуалізації ливарної машини та прокатного стану

Програмне забезпечення цього вікна дозволяє здійснити з анімацією вмикання в роботу ливарної машини та прокатного стана, керування їх швидкістю в ручному режимі, відслідковування вторинними приладами значень контрольованих і регульованих параметрів, формування траєкторії руху катанки від кристалізатора до прокатного стану та автоматичне регулювання теплового режиму кристалізатора, довжини заготовки і температури катанки після прокатного стану.

Програма регулювання теплового режиму кристалізатора за розрахованими значеннями кількості теплоти, що виноситься із заготовкою з кристалізатора, і кількості теплоти, що втрачається з охолодною водою, приведенана рисунку 7. Вона включає 9 основних фррагментів: моделі кристалізатора 1 i транспортного запізнювання (2), блоки формування 6 і увімкнення 4 збурень, блоки розрахунку кількості теплоти, що виноситься із заготовкою з кристалізатора 8, і кількості теплоти, що втрачається 3 охолодною водою 9, та блоки ПІ-регулятора 3 і зміни його настройок 7. 


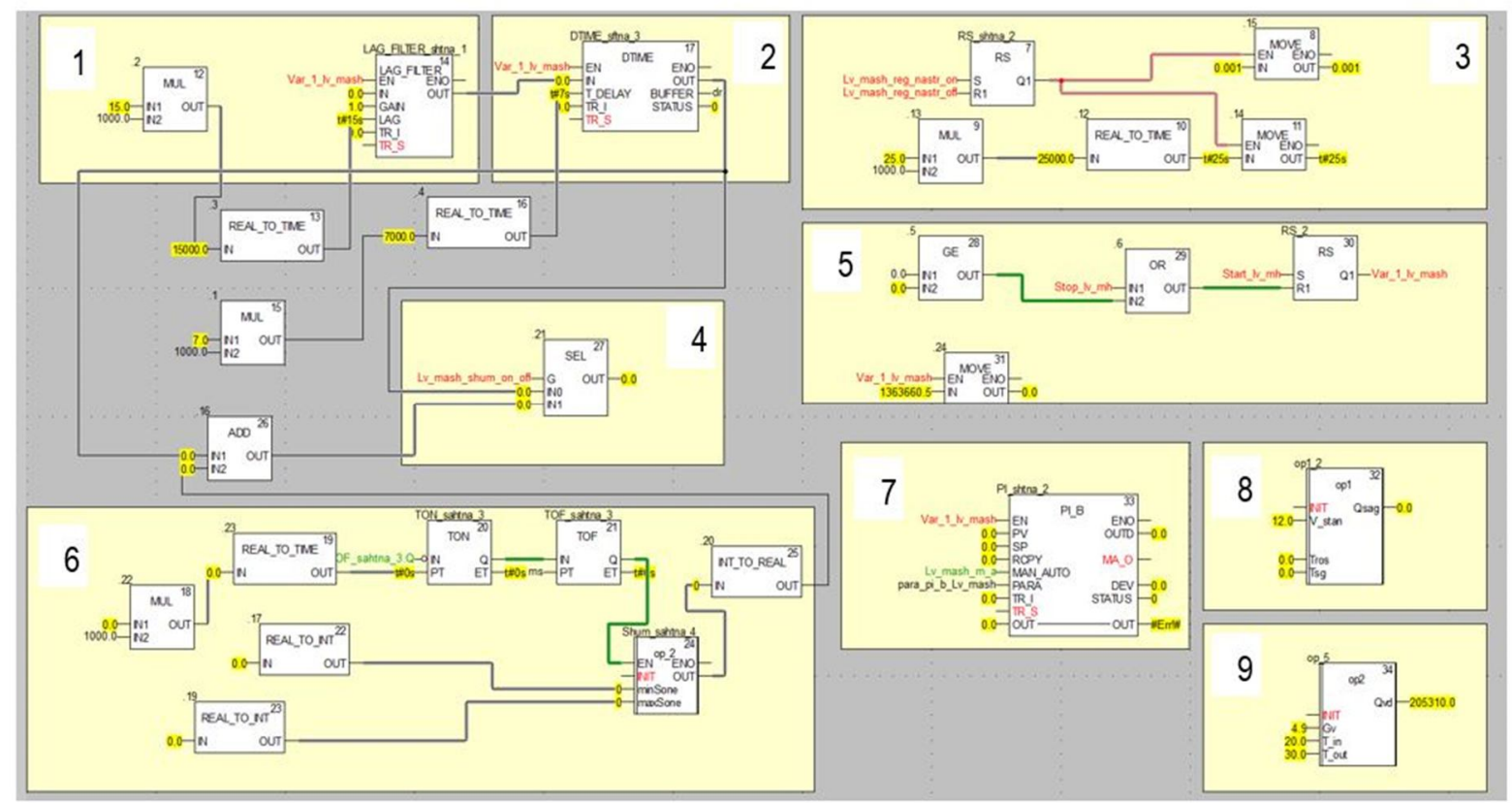

Рис. 7. Програма регулювання теплового режиму кристалізатора

На рисунку 8 показана панель настроювання САР теплового режиму кристалізатора і графік перехідного процесу після встановлення заданого значення кількості теплоти, що виноситься із заготовкою з кристалізатора, при появі випадкових збурень та після зменшення завдання.

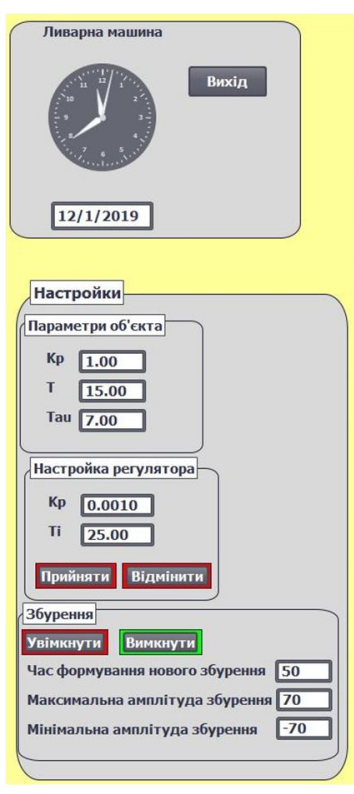

a)

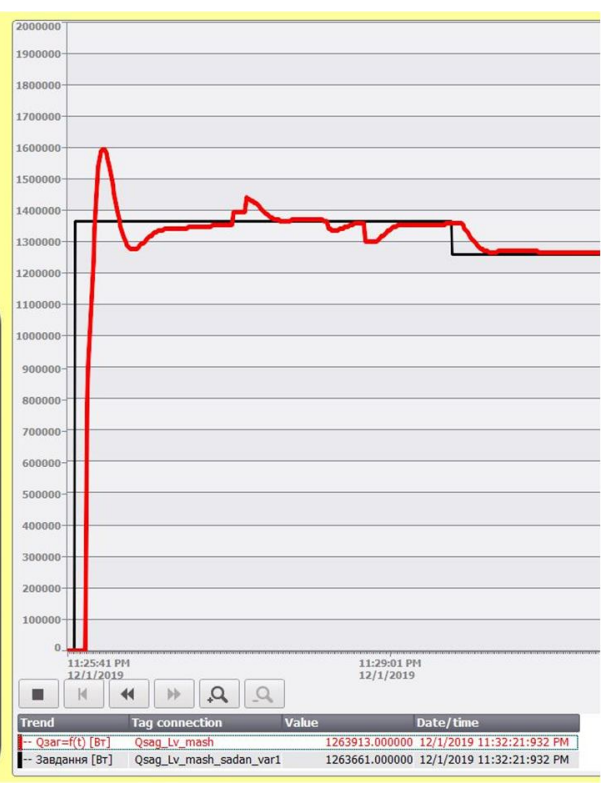

б)

Рис. 8. Панель настроювання САР теплового режиму кристалізатора (а) та графрік перехідного процесу при зміні завдання та під впливом випадкових збурень (б)

Програма імітації роботи системи автоматичного регулювання довжини заготовки приведена на рисунку 9. Основними у їі структурі $€$ функціональні блоки, що формують петлю заготовки та розраховують іï довжину між ливарним колесом і прокатним станом 2 , моделюють ПІ-регулятор 1 i надають можливість коригувати його настройки 3. 


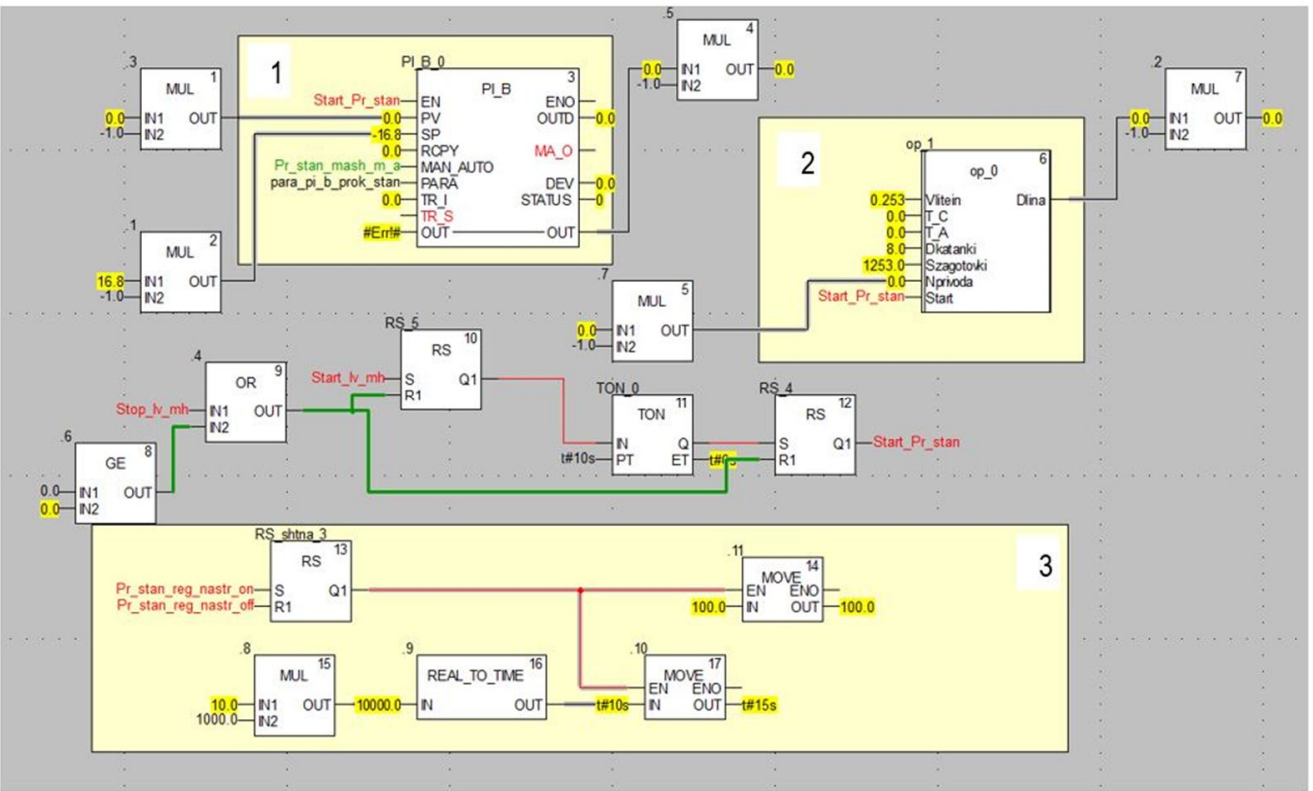

Рис. 9. Програма імітації формування заготовки та регулювання її довжини

У третьому вікні імітатора представлено пристрій для гартування й охолодження катанки та здвоєна моталка кошикового типу. Також передбачені візуальні засоби контролю та керування відповідними технологічними параметрами (рис. 10). 3 пульта оператора за допомогою кнопок можна увімкнути в роботу та вимкнути моталку, настроїти її роботу на відповідний діаметр катанки із заданим кроком укладання. При цьому на екрані відбувається емуляція її роботи та графрік зміни швидкості виткоутворювача залежно від установлених параметрів формування бунта.

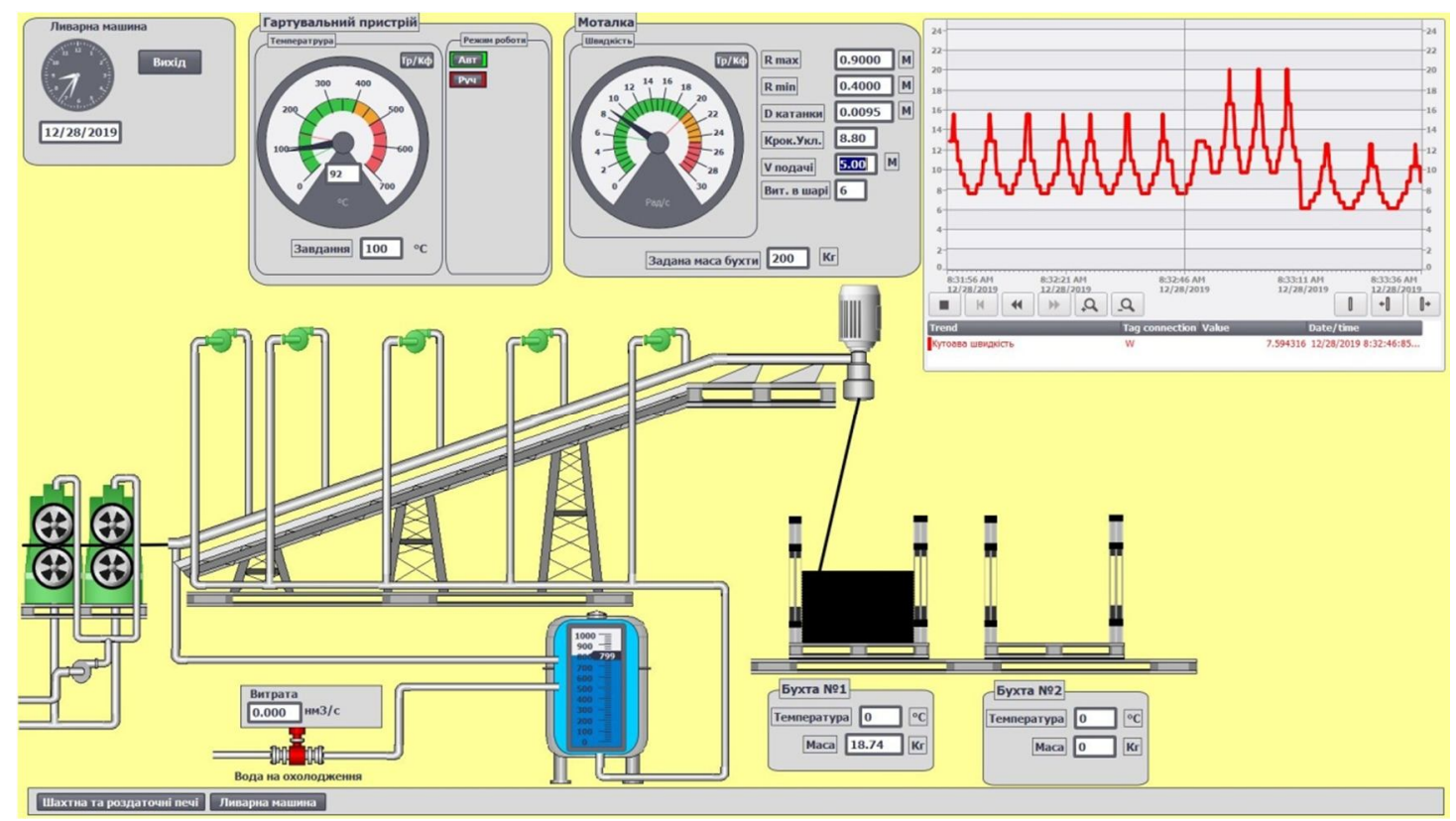

Рис. 10. Вікно візуалізації гартувального пристрою та здвоєної моталки

Код програми, що дискретно керує швидкістю виткоутворювача моталки, приведено на рисунку 11. У блоці 1 розраховується кількість витків у шарі, у блоках 2 і 4 - кутова швидкість проводки виткоутворювача при укладанні витків, відповідно, від периферії до центру і навпаки, а у блоках 3 і 5розраховується час формування витків при кожній швидкості виткоутворювача. 


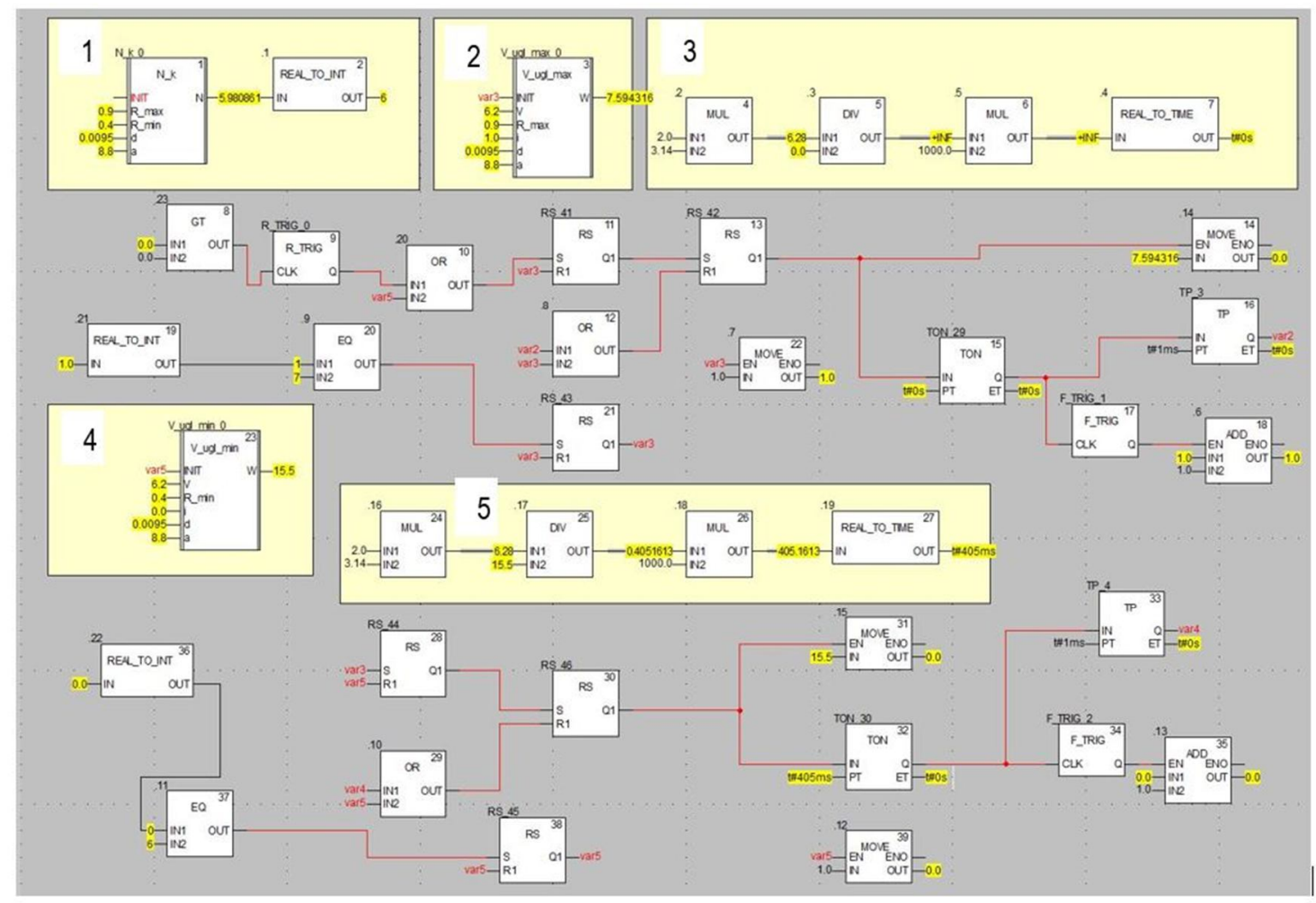

Рис. 11. Програма керування швидкістю виткоутворювача моталки

\section{IV Обговорення}

Впровадження сучасної АСУТП не може бути повноцінним без організації тренажерної підготовки експлуатаційного персоналу ще до початку впровадження реальної АСУТП на об'єкті [20]. Проте коли запускається в роботу нове виробництво без належного технологічного супроводу і оснащення системами автоматизації виникає проблема не тільки в підготовці кадрів відповідного профілю, а і в чіткому розумінні технологічних процесів, та способах управління. Якщо ж по даному виробництву бракує доступної інформації, як у випадку з технологією отримання алюмінієвої катанки методом безперервного лиття та прокатки, при розробці імітаційної моделі головне не отримання якісного тренажера для робітників реальної АСУТП, а створення зручного інструменту для моделювання роботи всієї технологічної лінії, окремих ії агрегатів і дільниць, систем автоматичного регулювання та дослідження якості їх роботи під впливом внутрішніх і зовнішніх збурень задля придбання певного досвіду в налагоджені та експлуатації технологічної лінії, а також в керуванні та обслуговуванні АСУТП. Для досягнення цієї мети на підставі літературного аналізу вибрані існуючи та запропоновані нові математичні залежності між параметрами технологічного процесу, а також системи регулювання і алгоритми управління. Так тепловий режим кристалізатора зазвичай стабілізується шляхом керування витратою охолодної води за різницею ї̈ температур до та після кристалізатора [21,22]. Проте цей спосіб не дозволяє змоделювати вплив вхідних параметрів на роботу системи автоматизації, тому в імітаційній моделі запропоновано регулювання теплового режимуза розрахованими параметрами (3) і (4), які напряму характеризують його стан і надають можливість дослідити якість регулювання при певних коливаннях витрати алюмінієвого розплаву, його початкової та кінцевої температури у виливниці, витрати охолодної води та їі температури до та після кристалізатора.

При моделюванні системи автоматичного регулювання довжини заготовки використовується не одноконтурна система стабілізації їі петлі на виході з кристалізатора, а алгоритм (5), за яким можна дослідити якість регулювання не тільки за відхиленням довжини катанки, а і за збуреннями, що надходять з боку ливарного колеса та прокатного стану.

Оскільки існуючи способи керуваня роботою моталки [23] розроблені під певні технологічні вимоги і не дозволяють налаштувати ї̈ роботу з урахуванням діаметра катанки та кроку укладання витків, при 
створені імітатора АСУТП запропоновано рекомендації, що надають можливість налаштувати роботу моталки на будь-який алгоритм формування бунтів (6) і (7).

Програмне забезпечення імітатора АСУТП виробництва алюмінієвої катанки дозволяє реалізувати два ручних режими керування ливарно-прокатним агрегатом - вільний і зблокований, а також автоматичний. При реалізації вільного режиму управління, кожна група механізмів управляється самостійно, що дозволяє оператору вручну синхронізувати їх роботу. При зблокованому режимі робота всіх механізмів прив'язана до швидкості ливарного колеса, яка визначає продуктивність ливарнопрокатного агрегату. В автоматичному режимі регулювання технологічних параметрів та управління виробничими процесами відбувається у реальному часі. Передбачена можливість коригування коесріцієнтів в об'єктах автоматизації, зміни значень параметрів в алгоритмах керування, настройок регуляторів та активізації збурень, що впливають на хід технологічного процесу. Усе це створює можливості для імітування різних сітуацій у роботі пічної дільниці та ливарно-прокатного агрегату, а також відпрацьовувати дії оператора-технолога АРМ та наладників АСУТП.

\section{V Висновки}

Розроблена імітаційна модель АСУТП з виробництва алюмінієвої катанки на ливарно-прокатному агрегаті, за допомогою якої можна зрозуміти особливості технологічного процесу, принципи побудови систем автоматичного регулювання та управління, дослідити вплив окремих параметрів на хід технологічного процесу, придбати певний досвід роботи в якості оператора автоматизованого робочого місця та наладника АСУТП. Окрім того розроблений імітатор можна використовувати в якості наочного посібника при моделюванні систем автоматизації, програмуванні мікропроцесорних контролерів, створенні людино-машинного інтерфейсу при проектуванні АСУТП та налагоджені її роботи.

\section{Бібліографрічні посилання}

1. Быстрова И.Н. Имитационное моделирование как современная технология обучения будущих специалистов в вузе. URL : http://t21.rgups. ru/archive/doc2007/4/05.doc. (дата звернення: 15.11.2019).

2. Константинов Е. В., Тимченко В. С. Применение имитационного моделирования в учебном процессе транспортного ВУЗа. Интернет-журнал «Мuр науки», 2015. №3. URL : http://mir-nauki.com/PDF/42PDMN315.pdf. (дата звернення: 15.11.2019).

3. Раменская А. В. Обзор систем имитационного моделирования, используемых при подготовке бакалавров. URL : https://scholar.google.ru/citations?user=tUyOY4IAAAAJ\&hl=ru (дата звернення: 15.11.2019).

4. Дозорцев В. М. Обучение операторов технологических процессов на базе компьютерных тренажеров. Приборы и системы управления. 1999. №8. С. 61-70.

5. Ахметсафин Р., Ахметсафина Р., Курсов Ю. Разработка тренажёров и отладкапроектов АСУТП на базе пакетов MMI/SCADA. Современные технологии автоматизации. 1998. №3. С. 38-41.

6. Spanel U., Kreutz M., Roggatz C. Simulator Based Operator Training. International Journalof Distributed EnergyResources. 2006. №2. Рp. 3-6.

7. Луцкая Н. Н., Пупена А. Н., Швед С. Н. Создание имитационных моделей технологических процессов для отладки программ ПЛК и проектов SCADA. Автоматизация в промышленности. 2013. № 7. С. 50-54.

8. Far East (China) Group Limited. URL : http:// shcablemachinery.ru/1-4-continuous-casting-rolling-line. (дата звернення 10.04.19).

9. Ц Целиков, А. И. Металлургические машины и агрегаты: настоящее и будущее. Москва : Металлургия, 1979. 144 с.

10. Сезоненко Ю. Д., Сезоненко А. Ю. Плавильные и плавильно-раздаточные печи для алюминиевыX cплавов. URL : https:// lityo.com.ua/ plavilnye-i-plavilno-razdatochnye-pechi-dlya-alyuminievykh -splavov. (дата звернення: 25.11.2019).

11. Емельянов В. А. Тепловая работа машин непрерывного литья заготовок. Москва : Металлургия, 1988. 143 с.

12. Ніколаєнко А. М., Трегулова І. П., Баришенко О. М. Дослідження теплообміну в роторній ливарній машині. Металургія. Наукові праці Запорізької державної інженерної академії. 2019.Випуск 1 (41). С. 64-69.

13. Спосіб охолодження зливка у роторній ливарній машині. Пат. № 135698 Україна; заявл. 14.02.2019; опубл. 10.07.2019, Бюл. № 13.

14. Спосіб регулювання теплового режиму кристалізатора у роторній ливарній машині. Пат. № 136035 Україна; заявл. 18.03.2019; опубл. 25.07.2019, Бюл. № 14.

15. Таранцева К. Р., Таранцев К. В. Процессы и аппараты химической технологи в технике защиты окружающей среды: учеб.пособ. Москва : НИЦ ИНФРА-М, 2014. 412с.

16. Ніколаєнко А. М., Таран Ю. П., Чумак Є. Т. Проектування системи автоматизації за допомогою Microsoft Visual Basic. Інженерні та освітні технології в електротехнічних і комп'ютерних системах. Кременчук: КрНУ, 2013. Вип.4. С. 4755. URL : http://eetecs.kdu.edu.ua/2013_04/EETECS2013_0406.pdf. (дата звернення: 25.11.2019). 
17. Спосіб формування бунта в моталках з осьовою подачею катанки. Пат. № 129203 Україна; заявл. 16.04.2018; опубл. 25.10.2018, Бюл. № 20 .

18. Пупена О. М., Ельперін І. В. Програмування промислових контролерів у середовищі Unity Pro : навч. посіб. Київ : Ліра-К, 2017. $376 \mathrm{c}$.

19. Руководство по программированию S7-1200/S-1500. Entry-ID: 81318674, V1.4,11/2015. 109 c. URL : https://ecshop.com.ua /files/ programming_S7_1200_1500.pdf_(дата звернення: 15.10.19).

20. Дозорцев В. М. Компьютерные тренажеры реального времени для обучения и переподготовки операторов и технологического персонала потенциально опасных производств. Приборы и системы управления. 1996. №8. С. 3031.

21. Глинков Г. М., Маковский В. А. АСУТП в черной металлургии: Москва : Металлургия, 1999. 310 с.

22. А. с. 197099 СССР, Кл. 31с.21, МПК В22d.Способ управления тепловым режимом / Краснов Б. И. (СССР). № 1015958/22-2; заявл. 21.06.1965; опубл. 31.05.67, Бюл. №9. 2 с.

23. Некипелов, В. С. Оборудование для намотки сортового проката и катанки. Теория иконструкции:учеб.пособ. Москва : Инфра-Инженерия, 2018. 140 с.

\section{References}

1. Bystrova, I. N. (2007). Imitatsionnoye modelirovaniye kak sovremennaya tekhnologiya obucheniya budushchikh spetsialistov v vuze. [Simulation as a modern technology for training future specialists at a university]. URL: http:// t21.rgups.ru/archive/doc 2007/4/05.doc. (accessed: 15.11.2019). [in Ukrainian]

2. Konstantinov, E. V., Timchenko, V. S. (2015). Primeneniye imitatsionnogo modelirovaniya $\mathrm{v}$ uchebnom protsesse transportnogo VUZa [The use of simulation in the educational process of a transport university.] Internet-magazine "World of Science", No. 3. URL: http://mir-nauki.com/PDF/42PDMN315.pdf. (accessed:15.11.2019). [in Ukrainian]

3. Ramenskaya, A. V. (2019). Obzor sistem imitatsionnogo modelirovaniya, ispol'zuyemykh pri podgotovke bakalavrov [Review of simulation systems used in the preparation of bachelors]. URL: https://scholar.google.ru/citations?user= UyOY4IAAAAJ\&hl=ru (accessed:15.11.2019). [in Russian]

4. Dozortsev, V. M. (1999). Obucheniye operatorov tekhnologicheskikh protsessov na baze komp'yuternykh trenazherov [Training of technological process operators based on computer simulators]. Devices and control systems, 8, 61-70. [in Russian]

5. Akhmetsafin, R., Akhmetsafina, R., Kursov, Yu. (1998). Razrabotka trenazhorov i otladka proyektov ASUTP na baze paketov MMI/SCADA [Development of simulators and debugging of process control systems based on MMI / SCADA packages]. Modern automation technology, 3, 38-41. [in Russian]

6. Spanel, U., Kreutz, M., Roggatz, C. (2006). Simulator Based Operator Training. International Journalof Distributed Energy Resources, 2, 3-6.

7. Lutskaya, N. N., Pupena, A. N., Shved, S. N. (2013.) Sozdaniye imitatsionnykh modeley tekhnologicheskikh protsessov dlya otladki programm PLK i proyektov SCADA [Creation of simulation models of technological processes for debugging PLC programs and SCADA projects]. Automation in industry, 7, 50-54. [in Ukrainian]

8. (2019). Far East (China) Group Limited. URL: http:// shcablemachinery.ru/ 1-4-continuous-casting-rolling-line (accessed: 10.04.19). [in Chinian]

9. Tselikov, A. I. (1979). Metallurgicheskiye mashiny i agregaty: nastoyashcheye i budushcheye. present and future [Metallurgical machines and assemblies: present and future]. Metallurgy, Moscow, Russia, 144. [in Russian]

10. Sezonenko, Yu. D., Sezonenko, A. Yu. (2017). Plavil'nyye i plavil'no-razdatochnyye pechi dlya alyuminiyevykh splavov [Melting and smelting and distributing furnaces for aluminum alloys.] URL: https:// lityo.com.ua/ plavilnye-i-plavilno-razdatochnye-pechidlya-alyuminievykh -splavov (accessed:25.11.2019). [in Russian]

11. Emelyanov, V. A. (1988).Teplovaya rabota mashin nepreryvnogo lit'ya zagotovok. [Thermal performance of continuous casting machines]. Metallurgy, Moscow, Russia, 143. [in Russian]

12. Nikolaienko, A. M., Tregulova, I. P., Barishenko, O. M. (2019). Doslidzhennya teploobminu v rotorniy lyvarniy mashyni. Metallurgy [Study of heat transfer in a rotary casting machine]. Scientific works of Zaporizhzhya State Engineering Academy, 1 (41), 64-69. [in Ukrainian]

13. (2019). Sposib okholodzhennya zlyvka u rotorniy lyvarniy mashyni.[A method of cooling the ingot in a rotary casting machine.] Stalemate. No. 135698 Ukraine; claimed 02/14/2019; publ. 10/07/2019, Bul. № 13. [in Ukrainian]

14. (2019). Sposib rehulyuvannya teplovoho rezhymu krystalizatora u rotorniy lyvarniy mashyni. [A method of regulating the thermal regime of the mold in a rotary casting machine ]. Stalemate. No. 136035 Ukraine; claimed 03/18/2019; publ. 25/07/2019, Bul. № 14. [in Ukrainian]

15. Tarantseva, K. R., Tarantsev, K. V. (2014). Protsessy i apparaty khimicheskoy tekhnologi v tekhnike zashchity okruzhayushchey sredy [Processes and devices of chemical technologists in environmental protection technology] : textbook. benefits, Moscow, Russia: SIC INFRA-M, 412. [in Russian]

16. Nikola€nko, A. M., Taran, Yu. P., Chumak, Є. T. (2013). Proektuvannya systemy avtomatyzatsiyi za dopomohoyu Microsoft Visual Basic [Designing an automation system using Microsoft Visual Basic]. Engineering and educational technology in electrical and computer systems, 4, 47-55. URL: http://eetecs.kdu.edu.ua/2013_04/EETECS2013_0406.pdf. (accessed 25.11. 2019). [in Ukrainian]

17. (2018). Sposib formuvannya bunta v motalkakh z osiovoyu podacheyu katanky.[Method of forming riot in coils with axial feed of wire rod]. Stalemate.No. 129203 Ukraine; claimed 16.04.2018; publ. 10.25.2018. [in Ukrainian] 
18. Pupena, O. M., Elperin, I. V. (2017). Prohramuvannya promyslovykh kontroleriv u seredovyshchi UnityPro. Programming of industrial controllers in UnityPro environment.]environment: textbook. Kyiv, Lira-K, 376. [in Ukrainian]

19. (2015). Rukovodstvo po prohrammyrovanyyu S7-1200/S-1500.[Programming Guide S7-1200/S-1500.] Entry-ID: 81318674, V1.4, 11/2015. 109. Retrieved fromhttps://ecshop.com.ua /files/ programming_S7_1200_1500.pdf. (accessed: 15.10.19).

20. Dozortsev, V. M. (1996). Komp'yuternyye trenazhery real'nogo vremeni dlya obucheniya i perepodgotovki operatorov i tekhnologicheskogo personala potentsial'no opasnykh proizvodstv [Real-time computer simulators for training and retraining of operators and process personnel of potentially hazardous industries]. Devices and control systems, 8, 30-31. [in Russian]

21. Glinkov, G. M., Makovsky, V. A. (1999). ASUTP v chernoy metallurgii [ Automated process control systems in the steel industry]. Metallurgy, Moscow, 310. [in Russian]

22. Krasnov, В. I. (1965). The method of controlling the thermal regime 197099 USSR, Кл. 31с.21, MPК V 22d.Sposob upravleniya teplovym rezhimom(SSSR).1015958/22-2; declared 21.06.1965, No 9. [in Russian]

23. Nekipelov, V. S. (2018). Oborudovaniye dlya namotki sortovogo prokata i katanki.Teoriya i konstruktsii [Equipment for winding long products and wire rod. Theory and construction]: textbook. benefits: Infa-Engineering,Moscow, 140. [in Russian]

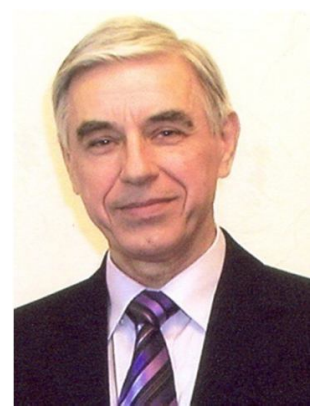

Ніколаєнко Анатолій Миколайович,

к. техн. Н., доцент, професор кафедри автоматизованого управління технологічними процесами, Інженерний інститут Запорізького національного університету,

пр. Ювілейний, 12, кв. 41, Запоріжжя, Україна, 69114.

Тел. +38(097)926-08-02 . E-mail: tetri@ukr.net

\section{Nikolaienko Anatoliy Mykolayovych.}

Cand.Sc. (Eng.), Associate Professor, Professor, Department of Automated Process Control, Engineering Institute of Zaporizhzhya National University,

12 Jubilee Ave.41, Zaporizhzhya, Ukraine, 69114.

Phone. +38(097)926-08-02 . E-mail: tetri@ukr.net

ORCID: https://orcid.org/0000-0002-2588-6907

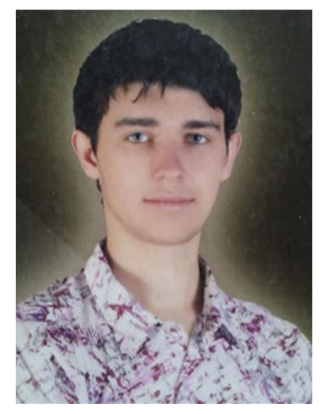

Якушевич Іван Вікторович.

магістрант кафедри автоматизованого управління технологічними процесами,

Інженерний інститут Запорізького національного університету,

вул. Тригубенка 19, Запоріжжя, Україна, 69114.

Тел. +38(098)268-18-01. E-mail: jakushevich96@gmail.com

Yakushevich Ivan Viktorovich.

Undergraduate of the Department of Automated Process Control,

Engineering Institute of Zaporizhzhya National University,

Trigubenko St., 19, Zaporozhye, Ukraine, 69114.

Phone: +38(098)268-18-01. E-mail: jakushevich96@gmail.com

ORCID: https://orcid.org/0000-0001-9925-178X

\section{Citation (APA):}

Nikolaienko, A., Yakushevich, I. (2019). Development of a simulation model of process control systems as a tool in modern training technology. Engineering and Educational Technologies, 7 (4), 96-109. doi: https://doi.org/10.30929/2307-9770.2019.07.04.08

\section{Цитування (ДСТУ 8302:2015):}

Ніколаєнко А. М., Якушевич І. В. Розробка імітаційної моделі АСУТП, як засобу в сучасній технології навчання / Інженерні та освітні технологї̈. 2019. Т. 7. № 4. С. 96-109. doi: https://doi.org/10.30929/2307-9770.2019.07.04.08

Обсяг статmі: сторінок - 14 ; умовних друк. аркушів - 2,028. 